\title{
THE CONTINUUM: A NEW APPROACH TO THE PLACE OF TORT IN A CONTRACTUAL MATRIX
}

\author{
William Thomson*
}

\begin{abstract}
This paper discusses the approach that is taken in New Zealand to determining whether a tortious duty of care can exist across a contractual matrix. The two step approach adopted in the recent decision of the Court of Appeal in Rolls-Royce NZ Ltd v Carter Holt Harvey Ltd is fundamentally agreed with. A continuum is suggested for the balancing exercise in the tortious duty of care inquiry. This rationalises past cases and will hopefully provide guidance for future ones.
\end{abstract}

\section{INTRODUCTION}

The relationship between the law of contract and tort, especially negligence, has never been a simple one. Indeed, it has been said that the proper analysis of the law of obligations is one of the great juristic problems of the present time. ${ }^{1}$ It is now well recognised that concurrent liability in tort and contract is acceptable as a matter of principle. But what is still unclear is the approach to determining whether a tortious duty of care exists in a contractual context. This paper analyses the approach that is taken in New Zealand to imposing a tortious duty across a so-called contractual matrix, where the litigating parties are not in a direct contract with each other, but rather a web of contracts that creates an indirect contractual relationship.

The recent decision of the New Zealand Court of Appeal in Rolls-Royce NZ Ltd v Carter Holt Harvey Ltd is their latest on the topic. ${ }^{2}$ It adopts a two step approach to determining whether a tortious duty of care arises in a contractual matrix. First, the Court of Appeal asks whether tort should intervene. A balancing approach is used to answer that question, in which the contractual matrix is considered. Second, if tortious liability is established, it is necessary to look for any express exclusions or limitations of liability in the contractual matrix. This is seemingly at odds

\footnotetext{
* Submitted as part of the LLB(Hons) programme at Victoria University of Wellington.

1 Jane Swanton "Concurrent Liability in Tort and Contract: the Problem of Defining the Limits" (1996) 10 JCL 21, 21.

2 Rolls-Royce NZ Ltd v Carter Holt Harvey Ltd [2005] 1 NZLR 324 (CA) [Rolls Royce].
} 
with the approach that was suggested in the English case of Henderson v Merrett Syndicates Ltd. ${ }^{3}$ This paper argues that the preferable solution is to follow the more comprehensive methodology from Rolls Royce.

In order to rationalise the case law, this paper suggests a continuum for the negligence duty of care inquiry at the first step. The continuum reflects the weight to be given to the contractual matrix in the balancing exercise. The result in Rolls Royce is at one end of that continuum, where the balancing approach finds tortious liability unlikely. Professional liability cases are at the other end, where tortious liability is more likely. ${ }^{4}$ Next, to define the balancing approach and give more guidance as to where on the continuum a given case will fall, the previous case law is consolidated under three headings: the nature of the loss, the nature of the contracts and the nature of the parties. Finally, the effect of limitation clauses at the second step and the place of the Hedley Byrne cause of action are considered. ${ }^{5}$

\section{CONCURRENT LIABILITY IN TORT AND CONTRACT}

\section{A Accepted in Principle}

Once upon a time there was a rule against concurrent liability in tort and contract in New Zealand. ${ }^{6}$ The logic was that a contract entailed the parties voluntarily constructing their relationship in a certain way and determining their obligations to each other. ${ }^{7}$ Consequently, the law of tort would simply be meddling. Tipping J put the argument colourfully in Simms Jones Ltd v Protochem Trading New Zealand Ltd: "If the parties have chosen a contractual bed they should ordinarily be expected to lie in it alone, without the seductive company of tort."8

However, concurrent liability in tort and contract is now accepted as a matter of principle. The leading decision is from the House of Lords in Henderson, where Lord Goff found that there was no sound basis for a rule which automatically restricts the claimant to either a tortious or a contractual remedy. ${ }^{9}$ The New Zealand Court of Appeal accepted the decision in three successive cases several years later. ${ }^{10}$

3 Henderson v Merrett Syndicates Ltd [1994] 3 All ER 506 (HL) [Henderson].

4 See for example Price Waterhouse v Kwan [2000] 3 NZLR 39 (CA) [Price Waterhouse]; Allison v KPMG Peat Marwick [2000] 1 NZLR 560 (CA) [Allison v KPMG].

5 Hedley Byrne \& Co v Heller and Partners Ltd [1964] AC 465 (HL) [Hedley Byrne].

6 McLaren Maycroft \& Co v Fletcher Development Co Ltd [1973] 2 NZLR 100 (CA).

7 Astley v Austrust Ltd (1999) 197 CLR 1, 22-23 Gleeson CJ, McHugh, Gummow and Hayne JJ.

$8 \quad$ Simms Jones Ltd v Protochem Trading New Zealand Ltd [1993] 3 NZLR 369, 381 (HC) Tipping J.

9 Henderson, above n 3, 532-533 Lord Goff.

10 Riddell v Porteous [1999] 1 NZLR 1 (CA); Price Waterhouse, above n 4; Allison v KPMG, above n 4. 


\section{B Practical Advantages to the Litigating Parties}

It could reasonably be asked why we need to worry about concurrent liability in tort and contract. In most cases, there will be no advantage if an action is brought in tort rather than contract. Consequently, a plaintiff can simply rely on an action for breach of contract, which will be easier to make out because they do not have to prove fault. The quantum of damages will also generally be more favourable in contract. ${ }^{11}$

However, in some cases, an action in tort will be attractive to the plaintiff. This attraction was the impetus for the change to concurrent liability. First, and most importantly, the limitation period may start to run at different times. ${ }^{12}$ There are also different rules about remoteness of damages which are generally more favourable for actions in tort. ${ }^{13}$ Contribution can not be recovered in an action for breach of contract, although it can be where there is solely tortious liability or concurrent liability in both contract and tort. ${ }^{14}$

A tort action may also be attractive to the defendant. It is unclear whether the Contributory Negligence Act 1947 extends to claims for breach of contract. ${ }^{15}$ On the other hand, it clearly applies where there is tortious liability. ${ }^{16}$ If a plea of contributory negligence is successful, the court may apportion damages between the parties under the Contributory Negligence Act 1947 according to their fault.

On top of these advantages, tortious liability in a contractual matrix situation has the advantage of being the more direct remedy. The plaintiff avoids the hassle of having to claim along the contractual matrix. Furthermore, the contractual remedy available to the plaintiff in that situation may be thwarted by the insolvency of parties along that contractual matrix.

11 Tort damages are the amount that will return the plaintiff to the status quo before the wrong was committed (Livingstone v Rawyard Coal Co (1880) 5 AC 25, 39 (HL) Lord Blackburn), whereas in contract it is the amount that will put the plaintiff in the position they would have been in had there been no breach (Robinson v Harman (1848) 1 Exch 850, 855 Parke B). There is, however, a possibility of a punitive damage award in tort.

12 Stephen Todd (ed) The Law of Torts in New Zealand (4ed, Brookers, Wellington, 2005) 1004-1014.

13 Issaka Ndekugri "Concurrent Liability in Contract and Tort in the Construction Industry" (2000) 16 Const LJ 13, 14; Swanton, above n 1, 43.

14 Todd, above n 12, 949.

15 Todd, above n 12, 855; John Burrows, Jeremy Finn and Stephen Todd Law of Contract in New Zealand (2ed, Butterworths, Wellington, 2004) 795-799.

16 Burrows, Finn and Todd, above n 15, 796. 


\section{A TORTIOUS DUTY IN A CONTRACTUAL MATRIX}

The acceptance of concurrent liability in tort and contract as a matter of principle clearly applies to the contractual matrix situation. That point is not in issue here. The focus of this paper is on the approach the courts take to imposing a tortious duty of care when the parties are in a contractual matrix

\section{A The Approach in Rolls Royce}

Genesis made a contract (K1) with Carter Holt Harvey (CHH) to build a plant at their Kinleith Mill. ${ }^{17}$ Genesis subcontracted (K2) some of the work to Rolls Royce. There was no direct contractual relationship between $\mathrm{CHH}$ and Rolls Royce. Both contracts $\mathrm{K} 1$ and $\mathrm{K} 2$ contained limitation of liability clauses. A clause in $\mathrm{K} 1$ enabled $\mathrm{CHH}$ to require Genesis to take proceedings against Rolls Royce under K2 to enforce the contractual obligations in $\mathrm{K} 2$ for CHH's benefit. Therefore, a claim in contract was available to $\mathrm{CHH}$, albeit an indirect one. ${ }^{18}$ However, when Rolls Royce failed to perform $\mathrm{CHH}$ chose to sue Rolls Royce in negligence, giving rise to a tortious claim across a contractual matrix. The incentive for the claim in tort appears to be the advantage of tort's remoteness of damage rules - the main damages sought were for loss of profit from not being able to sell electricity.

Given that there was no physical damage and the negligent misstatement claim was being left for another day, the real issue was whether a conventional negligence duty of care could extend to that situation of economic loss. The Court of Appeal adopted a balancing exercise to consider whether it was fair, just and reasonable to impose a duty of care. ${ }^{19}$ The contractual matrix figured highly in this duty of care inquiry, along with other factors. That is, the contractual matrix was not merely relevant when looking for exclusions or limitations on any tortious obligation that arose. It was also fundamentally relevant to whether such a tortious obligation arose in the first place. ${ }^{20}$

\section{B The Approach in Earlier Cases}

Concern about concurrent liability in a contractual matrix was raised prior to Rolls Royce when the New Zealand Court of Appeal released its decision in R M Turton \& Co Ltd (In Liq) v Kerslake and Partners. ${ }^{21}$ The majority of the Court of Appeal adopted the balancing approach subsequently

17 Rolls Royce, above n 2, 329-332 Glazebrook J for the Court.

18 Rolls Royce, above n 2, 351 Glazebrook J for the Court.

19 Rolls Royce, above n 2, 340-342 Glazebrook J for the Court.

20 Rolls Royce, above n 2, 342 Glazebrook J for the Court.

21 R M Turton \& Co Ltd (In Liq) v Kerslake and Partners [2000] 3 NZLR 406 (CA) [Turton v Kerslake]. 
used in Rolls Royce. They held that the existence of a contractual matrix is fundamentally relevant to the decision whether it is appropriate to impose a duty in tort: ${ }^{22}$

$[\mathrm{T}]$ he main and now accepted rationale behind the contractual matrix principle is concerned not with the existence of a contractual remedy, but with the way in which contractual intention can help to enlighten the often difficult question of when the relationship between the two parties is such as to warrant the intervention of the general law of tort.

Professor Todd criticised the decision in Turton $v$ Kerslake for reintroducing a modified form of the "no concurrent liability" rule in an uncertain way. ${ }^{23}$ Further, he said: "There is no, or no adequate, explanation of which contractual relationships or structures will have this effect and which will not, nor, where the principle does apply, why exactly it should do so."24 Thomas J, in his dissent in Turton $v$ Kerslake, felt that it was signalling a move back to primacy of contract in the contractual matrix situation. ${ }^{25}$ Both Professor Todd and Thomas $\mathrm{J}$ seem to have felt that the decision in Turton $v$ Kerslake, in rejecting a duty of care because of the specific contractual matrix in that case, signalled a return to primacy of contract in some sense.

On this argument, Henderson must have adopted a different approach whereby concurrent liability would always arise, subject only to exclusion or limitation in the contractual matrix. Indeed, Henderson can be interpreted in this way. The case concerned the liability of managing agents at the Lloyd's Insurance Society to underwriting members, known as 'names'. There were two sorts of name: direct names had contracts with their managing agents, whereas indirect names had contracts with members' agents, who in turn had contracts with the managing agents. Therefore, the direct names were in a direct contractual relationship with the managing agents, whereas the indirect names were in a contractual matrix with them. In finding the managing agents liable in tort to both the direct and indirect names, Lord Goff said: ${ }^{26}$

I do not find it objectionable that the claimant may be entitled to take advantage of the remedy which is most advantageous to him, subject only to ascertaining whether the tortious duty is so inconsistent with the applicable contract that, in accordance with ordinary principle, the parties must be taken to have agreed that the tortious remedy is to be limited or excluded.

22 Turton $v$ Kerslake, above n 21, 410 Henry and Keith JJ.

23 Stephen Todd (ed) The Law of Torts in New Zealand (3ed, Brookers, Wellington, 2001) 8.

24 Todd, above n 23, 234.

25 Turton $v$ Kerslake, above n 21, 432-433 Thomas J.

26 Henderson, above n 3, 532-533 Lord Goff. 
Thus Lord Goff was of the view that tortious obligations arise "irrespective of contract", 27 and then can only be defeated if explicitly excluded in the contract. That is, the contractual setting is irrelevant at the duty of care inquiry and is only turned to once a duty of care is established to see whether there is an exclusion or limitation of liability by that contractual setting. Furthermore, the New Zealand Court of Appeal seemed to follow the same approach in the matrix cases of Allison $v$ KPMG Peat Marwick and Price Waterhouse $v$ Kwan. In Allison $v$ KPMG it was said that "[c]oncurrent liability in contract and tort is now accepted, other than where it would permit a plaintiff to circumvent or escape a contractual exclusion or limitation of liability."28

On the face of it then, the approach in Turton $v$ Kerslake and Rolls Royce is at odds with that in Henderson. Andrew Beck outlined the difference: ${ }^{29}$

It may not be obvious, but the starting point of the majority [in Turton $v$ Kerslake] is diametrically opposed to that in [Price Waterhouse v] Kwan. The question posed was not whether the contractual arrangements had negated all negligence liability of Kerslake, but whether Kerslake had any duty at all given the contractual structures. The question was phrased as "should tort intervene?" rather than "has tort been excluded?".

Thus, the approach in Rolls Royce is to first ask: "should tort intervene?" This is where the balancing approach occurs. Only if a tortious obligation is established is it necessary to ask: "has tort been excluded?" This makes the contractual relationship relevant at two stages; when looking for a tortious obligation, and, if one exists, to see whether it explicitly limits or excludes liability. The Henderson approach is only to ask the second question: "has tort been excluded?"

Professor Todd and Thomas J's fear of a return to primacy of contract is understandable. It would not be in the best interests of the law because of the anomalies and injustices that it would create. However, the extra earlier step in Rolls Royce is not the adoption of a "no concurrent liability" rule. The Rolls Royce approach is a preferable way of dealing with tortious duties of care in a contractual matrix. It can also be entirely rationalised with how Henderson has been interpreted.

\section{The Preferable Approach}

The two-step Rolls Royce approach is more robust. This can be seen by analysing the basis for Lord Goff's approach in Henderson: the law of tort is the general law, out of which parties can, if they wish, contract. ${ }^{30}$ In what is really a pro-liability stance, it misses a crucial step. Tort is only the general law in any given situation if it arises in that situation. Whether a tortious duty of care

27 Henderson, above n 3, 533 Lord Goff.

Allison v KPMG, above n 4, 582 Thomas J.

9 Andrew Beck "Contract" [2001] NZ Law Rev 67, 82.

30 Henderson, above n 3, 532 Lord Goff. 
arises in any given situation will, as has been recognised over many years, depend on the whole of the facts and the entire surrounding context. The contractual relationship is part of that context and so should be weighed in the duty of care inquiry just like anything else of relevance. That is the fundamental approach to modern tortious negligence liability.

It could be argued that the nature of the duties in contract and tort are the same, and hence the contractual matrix does not need to be considered in the balancing approach. However, any such argument must fail because the nature of the claim is different between the two causes of action. This is quite different from the classic concurrent liability situation where the plaintiff has a direct contract with the alleged tortfeasor. In that case, the alleged tortfeasor would be concurrently liable for the same act to the same person and so the nature of the duty is the same in both tort and contract. However, in the matrix case they would be concurrently liable for the same act to different people. The nature of the duty is fundamentally different between tort and contract; it is to the middle party in contract and to the plaintiff in tort. In a contractual matrix case at least, the question "should tort intervene?" is a necessary precursor to the question "has tort been excluded?"

As already argued, this two question approach is not a rejection of concurrent liability. On the contrary, it is simply a refinement of the approach to situations in which tortious liability is alleged in a contractual matrix. Concurrent liability is the end result of that approach if a tortious obligation is found to exist. In that sense, it is just a label which has no extra meaning. In fact, the phrase concurrent liability is misleading in matrix cases and can be discarded. The better way to explain the situation is simply that tortious liability is possible within a contractual matrix, and whether it exists will depend on the individual circumstances.

\section{THE CONTINUUM}

Preference for the Rolls Royce approach does not mean that the results in Henderson and the early New Zealand cases following it are necessarily incorrect, or at odds with Rolls Royce. They can all be rationalised. These were all cases where tortious liability was highly likely if the balancing approach were used. Thus, they can be taken to have implicitly already asked whether tort should intervene, with the contractual setting effectively given no weight in the balancing exercise. The Court of Appeal in Attorney-General $v$ Carter implicitly reconciled the cases in this way, stating that in different cases the courts will inevitably highlight matters seen as particularly relevant in the individual circumstances. ${ }^{31}$ In other words, the courts did not highlight the contractual matrix in those cases because it was not seen as particularly relevant. If this view is taken, then Lord Goff's point in Henderson about tort being the general law out of which parties can willingly contract makes more sense. That is because it was confined to the facts at hand. In that case, tort was already implicitly established as the general law.

31 Attorney-General v Carter [2003] 2 NZLR 160, 170 (CA) Tipping J for the Court. 
This rationalisation suggests that sometimes the weight given to the contractual setting is effectively zero - when the question whether tort should intervene is implicitly considered. The logical progression of this, and the proposal in this article, is that there is in fact a continuum for the weight given to a contractual matrix in a negligence duty of care inquiry. At one end of the continuum, a tortious duty is highly likely. The weight given to the matrix in the inquiry will be so small as to be effectively zero. In other words, it is already considered that tort should intervene. This will be called the tort end of the continuum. Examples of this are the professional liability cases of Price Waterhouse and Allison v KPMG. At the other end, in cases like Rolls Royce, a tortious obligation is highly unlikely. Consequently, the weight given to the contractual matrix will be substantial. This will be called the contract end of the continuum. Of course, there will be many cases in between these two extremes.

An alternative way of looking at the proposal is to consider the way contractual and tortious duties are imposed. The basis for the initial rule against concurrent liability was that contractual liability was voluntarily assumed. The fact that tortious liability is court-imposed (in the sense that the general law is court-imposed) appears to be the basis for the suggestion that Henderson implies concurrent liability will always arise. But not all tortious duties are court-imposed and not all contractual liability is voluntarily assumed. Some contractual rules are imposed on contracting parties by the court without their knowledge. Likewise, it can be said that some tortious duties are self-imposed. An example of this is physical injury arising from the provision of a good or service. Putting aside the fact that compensatory damages are barred in New Zealand, ${ }^{32}$ after Donoghue $v$ Stevenson it could be said that manufacturers take it upon themselves to take care when they manufacture a potentially harmful product. ${ }^{33}$ It is not as obvious as people explicitly agreeing to enter into contracts and therefore taking on the liability imposed within them, but it is certainly arguable that it is implicit. The continuum follows from this point. At one end, in those cases where tortious liability is effectively voluntarily assumed, tortious liability will sit concurrently with any (also voluntarily assumed) contractual liability. At the other end, in those cases where a tortious duty would be court-imposed over and above contractual duties, the contractual matrix is given more weight. Like Rolls Royce, a tortious obligation is unlikely. Again, there will be many shades in between.

In rationalising the case law, the continuum approach also counters suggestions that separate approaches to concurrent liability exist in professional cases and those where there is physical damage. The suggestion has been that tortious liability always applies in both of those instances. However true that may be as an end result, it is preferable to realise these cases are just at one end of the continuum. If only one point is focussed on then narrow, distinct approaches like this will be arrived at. Yet broader principles and the bigger picture are more helpful in this area of the law, due

32 Injury Prevention, Rehabilitation, and Compensation Act 2001, s 317.

33 Donoghue v Stevenson [1932] AC 562 (HL). 
to its wide reach and general applicability. The continuum provides a consolidated, consistent and more robust approach that can be applied to any future contractual matrix case.

\section{THE IMPORTANT FACTORS}

The next step is to look in more detail at the approach to the first question of whether tort should intervene. This will provide a framework for determining where on the continuum a given case sits. Exactly what factors are weighed in the balancing approach? In Rolls Royce the Court of Appeal adopted an approach to the weighing exercise that consisted of evaluating many different factors and then, as if they were balls, throwing them in the air and seeing on which side of the tort/contract line they landed. It undoubtedly gave the correct result in that case, but it is not entirely methodical. Again, the continuum approach provides a superior framework. "Balls" that have been consistently "thrown in the air" in the case law have been grouped into relevant factors that better define the continuum. They are the nature of the loss, the nature of the contracts and the nature of the parties. These factors too are continuums upon which any given case will fall. The total result is then the sum of all three. The result is a more systematic and predictable approach to the weighing exercise. It should then be easier to determine where on the continuum a given case sits. It also shows how the important contractual matrix cases can be rationalised with the continuum approach.

\section{A Nature of the Loss}

1 Physical damage and personal injury

There has never been any difficulty with imposing tortious liability where a direct contract between the parties existed if physical damage to person or property occurs. This is subject, of course, to exclusion in the contract. A powerful example is that given by Oliver J in Midland Bank Trust Co Ltd v Hett Stubbs \& Kemp (a firm): "If I have a contract with my dentist to extract a tooth, I am not thereby precluded from suing him in tort if he negligently shatters my jaw." ${ }^{34}$ There is no reason to think the situation is any different in the case of a contractual matrix. Support for this view is found from Bingham LJ in Simaan General Contracting v Pilkington Glass Ltd, where he stated that there would have been a tortious duty across the contractual matrix if physical injury or damage to person or property had occurred. ${ }^{35}$ Of course, the ability to recover concurrently for physical injury in New Zealand is limited by the general inability to sue in negligence under the Accident Compensation scheme. ${ }^{36}$ It is important to recognise that physical damage to a thing itself is considered a defect and therefore economic loss. ${ }^{37}$

\footnotetext{
34 Midland Bank Trust Co Ltd v Hett Stubbs \& Kemp (a firm) [1978] 3 All ER 571, 598 (QB) Oliver J.

35 Simaan General Contracting v Pilkington Glass Ltd (No 2) [1988] QB 758, 769 (CA) Bingham LJ [Simaan].

36 Injury Prevention, Rehabilitation, and Compensation Act 2001, s 317.

37 Junior Books Ltd v Veitchi Co Ltd [1982] 3 All ER 201, 207 (HL) Lord Keith [Junior Books].
} 
This implies that where physical damage or personal injury occurs, the contractual matrix is effectively given no weight. This is the tort end of the continuum. The well known decision in Donoghue $v$ Stevenson supports this point. That case clearly involved a contractual matrix; there was a contract between Mrs Donoghue's friend and the shopkeeper and a contract between the shopkeeper and the manufacturer of the ginger beer. Although the victim, Mrs Donoghue, was not part of the contractual matrix, it would seemingly not have mattered if she had been. Thus, it shows that sometimes the contractual matrix is just not relevant - the extreme tort end of the continuum. Cooke P in South Pacific Manufacturing Co Ltd $v$ New Zealand Security Consultants \& Investigations Ltd noted that "[i]njury to the person is a kind of damage in a class of its own."38 While personal injury is easily seen as in a class of its own, damage to property is not. In the same case, Cooke P noted that damage to property is essentially economic loss. ${ }^{39}$ However, discussion of that point is beyond the scope of this article.

\section{Economic loss}

In Henderson, Lord Goff felt that if concurrent liability was accepted for personal injury, then there was no reason in principle to withhold it for economic loss, given the generalisation of negligence in the twentieth century. ${ }^{40}$ However, it comes at the other end of the continuum because it will generally point away from a duty of care in tort. ${ }^{41}$

(a) No tort of breach of contract

The main duty alleged by $\mathrm{CHH}$ in Rolls Royce was one to take reasonable care to ensure that the plant was constructed in accordance with the specifications contained in the contract to which $\mathrm{CHH}$ was not a party. The Court of Appeal took exception to this and held that: ${ }^{42}$

There is no duty in tort to take reasonable care to perform a contract. At most, there is a duty to take reasonable care in or while performing the contract, which is quite a different concept. ... A duty formulated in such terms is essentially contractual in nature and therefore cannot be owed to one who is not a party to the contract.

This distinction, albeit fine, clearly makes sense in the case of a contractual matrix. Any other result would effectively circumvent privity of contract and allow a third party to claim in tort for negligent non-performance of the contract according to its terms to which they were not a party.

38 South Pacific Manufacturing Co Ltd v New Zealand Security Consultants \& Investigations Ltd [1992] 2 NZLR 282, 296 (CA) Cooke P [South Pacific].

39 South Pacific, above n 38, 296 Cooke P.

40 Henderson, above n 3, 531 Lord Goff.

41 Rolls Royce, above n 2, 341 Glazebrook J for the Court.

42 Rolls Royce, above n 2, 342 Glazebrook J for the Court. 
The distinction is somewhat different in the case of a direct contract between the parties. The argument there is that if the contract is not met, then naturally the remedy should be contractual. A contrary result could make contract law redundant for negligent breaches of contract as per its specifications. Andrew Burrows also accepts this argument in the formulation of his "independence principle", which asserts that if a claim is, in essence, to enforce a contract then it should only be recoverable in contract. ${ }^{43}$

Thus, the Court of Appeal struck out the claim to the extent that it amounted to claiming a tortious obligation to perform a contract. However, for the purposes of the strike-out, the Court inquired as to whether there was a duty in more general terms. This is where they adopted the balancing approach. ${ }^{44}$ Once a tortious obligation to perform a contract is recognised as a fiction, then liability remains solely for the duties to take reasonable care while performing that contract. That is, duties to take reasonable care in tort may overlap with an implied duty of reasonable care in the contract.

(b) So what is left?

Therefore, any duty of care that remains for economic loss will be constrained by the content of the contracts. As the Court of Appeal in Rolls Royce pointed out, the recovery of economic loss in commercial situations gives rise to the difficulty in setting quality standards. ${ }^{45}$ This is because it cannot relate specifically to the contract which the plaintiff is not a party to, as that would give rise to a tortious obligation to perform a contract. This is especially so with commercial construction contracts for specialist plant with detailed specifications. ${ }^{46}$ The Court of Appeal in Rolls Royce was also reluctant to differ from the body of cases specifically approving the reasoning in Simaan, both in New Zealand and the United Kingdom, and subjecting the decision in Junior Books to much criticism. $^{47}$

In building a factory in the case of Junior Books, the plaintiff contracted with an architect, who subcontracted the laying of the factory floor to the defendant, thus creating a contractual matrix. The floor was laid incorrectly and within a couple of years it started to break up. The plaintiff sued in negligence for economic loss for the cost of replacing the floor and lost profits during the replacement period. The House of Lords held by majority that the defendant was liable in negligence.

43 Andrew Burrows Understanding the Law of Obligations: Essays on Contract, Tort and Restitution (Hart Publishing, Oxford, 1998) 20-21.

44 Rolls Royce, above n 2, 342-243 Glazebrook J for the Court.

45 Rolls Royce, above n 2, 342-343 Glazebrook J for the Court.

46 Rolls Royce, above n 2, 343 Glazebrook J for the Court.

47 Junior Books, above n 37. 
In Simaan, the plaintiff was the main contractor for a building. It subcontracted the incorporation of units of green glass to another company, who purchased the glass from the defendants. The glass was the wrong colour and so the building owner withheld payment from the plaintiff, who sued the defendant in negligence for economic loss. The English Court of Appeal held that no duty of care existed in tort.

The decisions in the two cases and their relationship have been the subject of much analysis. Even though Dillon LJ in Simaan thought Junior Books had been analysed to the point that it is no longer of any use, ${ }^{48}$ the two decisions can be sufficiently rationalised to fit within the continuum. In Simaan, Bingham LJ distinguished Junior Books on the basis it was a case concerned with physical damage, whereas in Simaan there was no damage at all - rather the glass was simply a different colour from what the contract required. ${ }^{49}$ However, this argument is incorrect in that it regards physical damage to the good supplied as physical damage to property. It is well recognised that this is regarded as a defect. ${ }^{50}$ Another possible distinction was raised in Rolls Royce: the floor in Junior Books was defective per se, whereas the glass in Simaan was only defective as per the contractual specifications. ${ }^{51}$ However, only one of their Lordships in the majority in Junior Books, Lord Keith, accepted that the tortious duty was based on the defectiveness of the floor per se; the other three thought the floor was defective as per the contractual specifications. Seemingly, if the floor in Junior Books was contractually meant to be one colour and turned out to be another, the House of Lords would still have allowed an action in tort for pure economic loss suffered by having to replace the floor.

The most likely interpretation of Junior Books (called the "wide" interpretation by some) is that defects in quality are always recoverable in commercial construction cases. The Court in Rolls Royce refused to recognise this as part of New Zealand law. ${ }^{52}$ This must be the correct result to the extent that Junior Books links the economic loss back to the contractual specification. Lord Brandon pointed this out in his dissent in Junior Books. ${ }^{53}$ The majority's decision was effectively imposing a tortious duty to perform a contract because it imposed a tortious duty to cover the situation where the losses arose from the failure to meet the contractual specifications.

Bingham LJ in Simaan also distinguished Junior Books on the basis that the building owner had nominated the subcontractor, and so it could be said that the subcontractor had assumed

48 Simaan, above n 35, 805 Dillon LJ.

Simaan, above n 35, 803 Bingham LJ.

Junior Books, above n 37, 207 Lord Keith.

Rolls Royce, above n 2, 347 Glazebrook $\mathrm{J}$ for the Court.

52 Rolls Royce, above n 2, 355 Glazebrook J for the Court.

53 Junior Books, above n 37, 218 Lord Brandon. 
responsibility. ${ }^{54}$ While this "narrow" interpretation has found favour with the courts (and indeed the Court of Appeal in Rolls Royce left it open for consideration in New Zealand), ${ }^{55}$ it seems to be a byproduct of the English Court of Appeal wriggling its way out of higher authority. Although technically bound by Junior Books, a case on all fours in all material respects, the Court of Appeal in Simaan appears to have distinguished it because they thought its reasoning was suspect. This is basically saying that it is not permissible to sue in tort for a failure to come up to the contractual standard.

While Simaan has contributed to the debate with its insights into how a tortious obligation would generally cut across allocations of risk in a contractual matrix in such a highly commercial case, we must not let it obscure the real point. ${ }^{56}$ Junior Books was incorrectly decided; there should be no tort to perform a contract as per its specifications. This will, in practice, mean that any defects in quality in cases with highly detailed contractual specifications will be unlikely to be recoverable in tort.

\section{B Nature of the Contracts}

1 Allocation of risk

In Rolls Royce, it was felt that the detailed contractual arrangements showed that the risk structure had been bargained for and allocated. ${ }^{57}$ The ability for $\mathrm{CHH}$ to require Genesis to sue Rolls Royce was seen as pointing to an intention on the part of the parties that these should be the only direct rights $\mathrm{CHH}$ should have against Rolls Royce. The presence of limitation clauses showed that $\mathrm{CHH}$ only paid for what was to be provided under that contract and it should not be able to improve on its bargain by direct suit in tort. Commercial certainty then required that these types of agreements not be meddled with.

Similar reasoning was adopted by Bingham LJ in Simaan. He felt that in such a commercial construction case there would be no assumption of responsibility (that is, for a Hedley Byrne based duty) because it would be inconsistent with the structuring and allocation of the risks between the parties. ${ }^{58}$ This is easy to understand in highly commercial cases. Not only will it harm settled expectations for the courts to meddle in highly detailed commercial allocations of risk, but there is also no pressing need for them to do so.

54 Simaan, above n 35, 803 Bingham LJ.

55 Rolls Royce, above n 2, 355 Glazebrook J for the Court.

56 See Part IV B 1 Allocation of risk.

57 Rolls Royce, above n 2, 350-352 Glazebrook J for the Court.

58 Simaan, above n 35, 781 Bingham LJ. 
In South Pacific, two years earlier than the decision in Henderson, the Court of Appeal looked at the question of tortious liability in a contractual matrix. The question was whether a professional investigator, employed by contract by an insurer to inquire into and report on the cause of the fire on the insured property, owed a duty of care to the insured (who had a contract with the insurer). Whilst all judges felt that there was clearly proximity, policy factors told against a duty of care. Although agreeing with the result in Simaan, Cooke P felt that the same problem was not met there - that is, there was not the same general allocation of risk and responsibility. ${ }^{59}$ Richardson J, on the other hand, implied that there was a risk allocation paid for via the contracts. ${ }^{60}$

Clearly, the nature of the contractual relationship (that is, the detail of the contracts and their terms) will bear on whether the matrix manifests an allocation of risk sufficient to point away from tortious liability. The auditors' liability cases are an example at the other end of the continuum from Rolls Royce. In Price Waterhouse, the Court of Appeal considered a contractual matrix; clients of a firm of solicitors were suing the auditors of the firm's nominee company for negligent audit reports. In Allison v KPMG the purchaser of a business sued the auditors for a negligently prepared report of that business' accounts. The vendor had a contract with the auditors and the purchaser had a warranty contract with the vendor, creating a contractual matrix. The Court of Appeal allowed tortious liability in both cases.

In Price Waterhouse, the Court of Appeal said that to "rely on the so-called contractual matrix for that proposition [that the risk structure had been allocated in that case] seems to us to be highly artificial."61 Thus, the Court of Appeal felt that the contracts were not detailed enough to show an allocation of risk. This was especially so in relation to the possibility of insolvency. The Court felt that the possibility of insolvency of the middle party in a contractual matrix was a good reason to allow tortious liability. Both the Court of Appeal in Allison v KPMG ${ }^{62}$ and Thomas $\mathrm{J}$ in Turton $v$ Kerslake, ${ }^{63}$ recognised the importance of the risk of insolvency in those cases. The fact that there was not an explicit mention of it in the contractual matrix showed that there was not an allocation of risk (at least of insolvency).

Risk allocation does not appear to explain why Lord Goff recognised such a duty in Henderson. The Court in Rolls Royce suggested that Henderson was different for two reasons. ${ }^{64}$ First, the efficient operation of the construction industry is based on the structured contractual allocation of

59 South Pacific, above n 38, 301 Cooke P.

60 South Pacific, above n 38, 308-309, Richardson J.

61 Price Waterhouse, above n 4, 45 Tipping J for the Court.

Allison v KPMG, above $\mathrm{n}$ 4, 582 Thomas $\mathrm{J}$.

63 Turton $v$ Kerslake, above n 21, 433 Thomas J.

64 Rolls Royce, above n 2, 346-347 Glazebrook J for the Court. 
tasks and risks at every step. Second, the structure of the Lloyd's Insurance Society requires maintaining parity of liabilities between the names. Neither argument is particularly convincing; the insurance industry, especially Lloyd's, would also appear to have a highly structured allocation of risk. Richardson J recognised this in South Pacific, an insurance case. ${ }^{65}$ Indeed, allocating risk is the very job of the insurance industry!

\section{Claim in contract still available?}

Most plaintiffs will bring their cause of action in the tort of negligence because their claim in contract is defective in some way; ranging from not being available at all, to just not as advantageous. Lack of a contractual claim would appear to make a tortious obligation more likely. In Price Waterhouse, the Court of Appeal found the auditor liable in tort because the remedy against the solicitor in contract was of little use. ${ }^{66}$

On the other hand, both Richardson J and Cooke P in South Pacific felt that any claim should be made in contract in that case because it would provide a reasonable, if not entirely comprehensive, remedy. ${ }^{67}$ This point is slightly unusual in the sense that the specific contracts were not in evidence. However, it can probably be explained on the basis that they were standard form insurance contracts. This reasoning was adopted by the Court of Appeal in Rolls Royce, who felt that the availability of a contractual remedy, albeit an indirect one, pointed away from a tortious duty of care. ${ }^{68}$

The point in South Pacific was that a 'reasonable' remedy was still available in contract. This would seem to suggest that although there may be a contractual remedy available, if it is not reasonable then a tortious obligation is more likely. The statement in Allison $v$ KPMG to the effect that a remedy in contract will not necessarily mean a tortious obligation is less likely fits with this analysis. ${ }^{69}$ That was a professional liability case, where the imbalance of power and knowledge is more likely to suggest an unreasonable remedy in contract. ${ }^{70}$

65 South Pacific, above n 38, 308-309 Richardson J.

66 Price Waterhouse, above n 4, 44 Tipping J for the Court.

67 South Pacific, above n 38, 304 Cooke P; 308 Richardson J.

68 Rolls Royce, above n 2, 351 Glazebrook J for the Court.

69 Allison v KPMG, above n 4, 582 Thomas J.

70 See Frost \& Sutcliffe $v$ Tuiara [2004] 1 NZLR 782, 786 (CA) Tipping J for the Court, where it was stated that a tortious claim could fill the gap left by an inappropriate limiting of liability in contract by a solicitor. 


\section{Nature of the Parties}

Some suggest that as a party is perfectly free to obtain separate contracts from subcontractors, then there is no need for tort protection in a contractual matrix situation. ${ }^{71}$ That is the case at the contract end of the continuum. The Court of Appeal in Rolls Royce appeared to support that contention. The parties were sophisticated commercial ones who were legally represented and there was no suggestion of an inequality of bargaining power. The Court of Appeal expected that such parties were capable of looking after their own interests. ${ }^{72}$ There was such a close relationship between the parties, and no imbalance of power, that it was clearly fair to assume that if direct action was wanted then it would have been provided for in contract. In other words, commercial contracting parties have the ability to protect themselves and so a tortious duty of care is less likely to arise.

However, some claim that this is not consistent with practice. Issaka Ndekugri points out: "[c]ommon practices in the construction industry suggest that the parties intend assumption of responsibility. For example, the need for collateral warranties is to achieve, by contractual means, the outcome denied in the decisions."73 But that is the point. When in such a detailed and close relationship, parties will usually be expected to contract for protection due to those contingencies rather than contract out of them.

Andrew Beck suggests that such an approach leads to the conclusion that there is no protection for the rich: ${ }^{74}$

While one may improve one's position by entering into a contract, the failure to do so should not result

in the forfeiture of the default position. Erosion of the basic standard could soon lead to a conclusion

that rich people do not deserve the same protection of the law as poor people.

However, the weighing approach effectively says that in some cases, Beck's "default position" never arose. The conduct and nature of the parties and their relationship strongly suggests that they did not want or need the law of tort to intervene. It also has nothing to do with the relative wealth, but rather the relative power and sophistication, of both parties to the transaction.

On the other hand, at the tort end of the continuum, sometimes a party is unable to protect themselves in contract. ${ }^{75}$ It may well often be impractical or too costly to have individual contracts.

71 I N Duncan Wallace Construction Contracts: Principles and Policies in Tort and Contract (Sweet \& Maxwell, London, 1986) 73.

72 Rolls Royce, above n 2, 353 Glazebrook J for the Court.

73 Ndekugri, above n 13, 29.

74 Andrew Beck "Contract" [2005] NZ Law Rev 53, 67.

75 John Fleming "Tort in a Contractual Matrix" [1995] Tort Law Rev 12, 22. 
After a loss occurs it often seems reasonable to say that the disappointed party could have sought direct contractual protection. But this ex post evaluation ignores the fact that the number of cases in which the performance is negligent is a very small fraction of all the contractual matrix situations. In some cases the costs of contracting for this remote contingency would more than likely outweigh the litigation costs under a liability regime. It is also clear that in some cases there will be a large number of parties so that individual contracting is inefficient. The default position provided by the tortious remedy can be seen as a standard form contract. Therefore, in some cases it will be more efficient to make it necessary for parties to contract for protection, and at other times it will be more efficient to make it necessary for parties to contract out of liability.

The courts seem to recognise this point. They will look to whether a party had the ability to obtain protection. The Court of Appeal in Rolls Royce called this the "vulnerability" of the plaintiff. $^{76}$ Such a factor explains the result in Henderson better than those reasons suggested in Rolls Royce. Although the Lloyd's Insurance Society was highly structured, the indirect names and direct names were, in most cases, ordinary everyday people. There was an imbalance of power between them and the managing agents that showed reliance by them on the agents.

Another example is the auditor liability cases, where there was no such supposition that the parties could have contracted. Although a business transaction was the substance of the relationship in Price Waterhouse, it was important that the auditors were appointed by the New Zealand Law Society. The Court of Appeal recognised how each client in that case did not have the capacity to obtain the sort of protection that a general auditor provides by each contracting with an individual auditor. ${ }^{77}$ The same reasoning applies to the domestic building cases, which often involve a contractual matrix. ${ }^{78}$

In all such cases, it could be said that clients of professionals are in a disadvantaged position visà-vis the professional. In Scott Group v MacFarlane, Woodhouse J discussed the point in relation to auditors. ${ }^{79}$ He felt that the auditors were in a special position because their status gave added quality to the reports that they were auditing and implied that it was safe to rely on them. ${ }^{80}$ Thus professionals are deemed to have special knowledge that gives them power over ordinary people because ordinary people rely on them. It is therefore to be expected that they are more careful and skilful in doing their job than other people. ${ }^{81}$

\footnotetext{
76 Rolls Royce, above n 2, 341 Glazebrook J for the Court.

77 Price Waterhouse, above n 4, 43 Tipping J for the Court.

78 See, for example, Invercargill City Council v Hamlin [1994] 3 NZLR 513 (CA).

79 Scott Group v MacFarlane and Others [1978] 1 NZLR 553 (CA).

80 Scott Group v MacFarlane and Others, above n 79, 575 Woodhouse J.

81 Nocton v Lord Ashburton [1914] AC 932, 946 (HL) Viscount Haldane LC.
} 
An anomalous case in this regard is Turton $v$ Kerslake. The plaintiff successfully tendered for the contract to build a hospital for the Southland Area Health Board. The Health Board contracted separately with a firm of architects to design the hospital, who then contracted with the defendant to advise on engineering. A heating system was installed based on specifications provided by the defendant. It was defective and the plaintiff had to fix it, so they sued the defendants in the tort of negligent misstatement. A majority of the Court of Appeal held that there was no tortious duty of care.

While in theory the plaintiff did have the ability to protect himself in contract, it seems unrealistic that contractors for a building project should have to contract with the designing engineer to gain protection for negligent design work. ${ }^{82}$ It is surely within the contemplation of the engineer that tenderers will rely on their specifications. Furthermore, the costs involved in checking the specifications themselves, if there is no tortious liability on the part of the engineer, would highly complicate and lengthen tendering. It would also mean that tenderers for building contracts would effectively be guaranteeing the engineer's work, and therefore make the engineer's work redundant.

\section{Hedley Byrne}

The Court of Appeal in Rolls Royce declined to strike out the Hedley Byrne claim, which included the question of whether Junior Books in its narrow manifestation (requiring an assumption of responsibility) is part of New Zealand law. ${ }^{83}$ It is understandable that the Court of Appeal did not strike out the negligent misstatement claim based on pre-contractual statements. As a well accepted and conventional claim, that clearly had a chance of succeeding at trial. Not surprisingly, the Court of Appeal said that they would adopt the same balancing approach to such a claim. ${ }^{84}$ However, both Andrew Burrows and Cooke P in South Pacific have warned that any tortious duty involving an assumption of responsibility generally in a contractual context would have to be well defined to avoid tortious obligations to perform a contract. ${ }^{85}$

The decision to leave the narrow Junior Books interpretation seems to be due to procedure. It was not pleaded and so could not be struck out. It is unfortunate that it was not pleaded, because it needs to be recognised by the Court of Appeal that it is not part of New Zealand law. As discussed above, this interpretation arose because the English Court of Appeal was trying to wriggle its way out of a binding House of Lord's decision. ${ }^{86}$ Now the Court of Appeal in Rolls Royce has recognised that there is no tortious obligation to perform a contract as per its specification.

82 See generally Turton v Kerslake, above n 21, 419-445 Thomas J dissenting.

83 Rolls Royce, above n 2, 355 Glazebrook J for the Court.

Rolls Royce, above n 2, 354 Glazebrook J for the Court.

85 Burrows, above n 43, 30-31; South Pacific, above n 38, 297 Cooke P. 
Therefore, the entire decision in Junior Books must be disregarded because that is what it stood for. Whether or not it is labelled an "assumption of responsibility" should not change the fact that there is no tortious obligation to perform a contract as per its specifications.

\section{THE EFFECT OF LIMITATION CLAUSES}

In Rolls Royce, the Court used limitation clauses in the balancing approach to see whether a duty of care should exist. ${ }^{87}$ Clearly, limitation and exclusion clauses will also be relevant if a tortious duty is established by the continuum approach. The second question must now be asked - has tort been excluded by the contracts?

\section{A Relying on Limitation Clauses}

Limitation clauses in the contract to which the plaintiff was a party (and the defendant was not) could be relied on by the defendant using the provisions of the Contracts (Privity) Act 1982. This was not discussed in Rolls Royce, but Professor Todd agrees that arguably Rolls Royce could have established that it was a sufficiently designated beneficiary of the contract between $\mathrm{CHH}$ and Genesis and was intended to have the benefit of that contract. ${ }^{88}$ The defendant could also use the Supreme Court of Canada's rule that a third party can rely on such an exclusion clause when the contractors intended reliance and the activities performed by the third party were contemplated as coming within the scope of the contract or of the particular provision in the contract. ${ }^{89}$

Limitation clauses in the contract to which the plaintiff was not a party (but the defendant was) are usually not relevant because the general rule is that it is not possible to put the burden of a contract on a non-consenting third party. ${ }^{90}$ However, comments in Rolls Royce suggest that in some cases they could possibly be relied on; the presence of a limitation clause in the contract, if known to the plaintiff, may give rise to non-contractual notice of the defendant's unwillingness to do the job otherwise than subject to the limitation. ${ }^{91}$ The plaintiff's acquiescence can then be deemed an acceptance of the terms upon which the defendant is willing to do the job. Also, for cases of negligent misstatement, there will be no assumption of responsibility if the other party has notice of the provisions. Alternatively, a disclaimer can be used.

87 Rolls Royce, above n 2, 352 Glazebrook $\mathrm{J}$ for the Court.

88 Stephen Todd "Tort" [2004] NZ Law Rev 585, 591.

89 London Drugs Ltd v Kuehne \& Nagel International Ltd [1992] 3 SCR 299; Fraser River Pile \& Dredge Ltd v Can-Dive Services Ltd [1999] 3 SCR 108.

90 Burrows, Finn and Todd, above n 15, 541.

91 Rolls Royce, above n 2, 352 Glazebrook J for the Court; Todd, above n 12, 879. 


\section{B Practical Effect}

The fact that limitation clauses may apply does not make the continuum approach redundant. They will not bar tortious actions in every case. In many, they will only limit the quantum of the damages, meaning that a tortious obligation may still be viable. This is especially so if there is no contractual claim available at all. Such a situation could arise if the contractual limitation period expired or the middle party in the contractual matrix was insolvent.

\section{CONCLUSION}

It is now clear that concurrent liability in tort and contract is generally accepted as a matter of principle. However, the decision in Henderson gave an impression that there was a strict approach to the existence of a tortious obligation in a contractual setting. The contractual context was irrelevant to whether a prima facie duty of care arose between the parties, and was only relevant to the extent that it expressly or implicitly limited or excluded any tortious liability.

However, the New Zealand Court of Appeal's recent decision in Rolls Royce demonstrates that the approach when there is a contractual matrix is more subtle than that. The contractual matrix is also relevant when inquiring whether a duty of care arises. Thus, the contractual matrix will be relevant at two stages: when looking for a tortious obligation, and, if one exists, to see whether the contracts explicitly exclude or limit liability. This does not symbolise the general rejection of concurrent liability. As an end result, concurrent liability is still possible. This approach is preferable because it follows the modern approach to negligence liability and recognises that the nature of the duties in contract and tort will be different.

In order to rationalise the case law, a continuum is suggested for the balancing exercise in the tortious duty of care inquiry. Any given contractual matrix will fall upon this. At one end will be the highly commercial cases like Rolls Royce where the contractual matrix points away from a tortious duty of care. At the other end, consumer product cases where personal injury is caused, like Donoghue $v$ Stevenson, will mean tortious liability is highly likely.

Three important factors have been deduced from the case law to fill out this continuum, and help to give guidance as to where on the continuum a given case will lie. They are the nature of the loss, the nature of the contracts and the nature of the parties. These basically comprise detailed analysis of the facts and elements of legal and public policy. This is not surprising, and was recognised by Cooke P in South Pacific, itself involving a contractual matrix, where he said that he was trying to "bring out the ineluctable importance of policy in this field." 92

Lawyers, judges and legal academics all strive for categorisation of the law. The purpose is to make the law comprehensible, manageable, and, above all, predictable. This ensures that the essential requirement of the rule of law is fulfilled: like cases will be treated alike. The continuum

92 South Pacific, above n 38, 299 Cooke P. 
approach attempts to simplify the categorisation of contractual matrix cases. It consolidates the disparate case law and is also more methodical than the Rolls Royce approach. Although it still seems somewhat hazy, that is because this area of law is inherently so. 
